удК 338.244.47

DOI https://doi.org/10.32837/yuv.v0i4.2228

О. Стогова,

кандидат політичних наук, доцент,

доцент кафедри фундаментальної юриспруденції та конституційного права

Сумського державного університету

\title{
ВПЛИВ ДЕЦЕНТРАЛІЗАЦІЇ ПУБЛІЧНОЇ ВЛАДИ НА СТАВЛЕННЯ ГРОМАДЯН ДО ЄВРОПЕЙСЬКОГО СОЮЗУ
}

Однією 3 актуальних проблем в Україні залишається децентралізація публічної влади. Незважаючи на те, що процес офіційно розпочався 3 квітня 2014 року і вже реалізовано два перші етапи, залишається безліч питань щодо оцінки ефективності проведеної реформи та подальшого Піі втілення в життя. Один із аргументів, що наводився прибічниками реформи і продовжує вживатися як незаперечний - це європейський досвід децентралізації, причому саме в такому формулюванні попри той факт, що досвід децентралізації країн Європи дуже відмінний, суттєво різниться у просторі й часі, в досягнутих результатах, а головне - в оцінці і ставленні громадян. Зважаючи на те, що децентралізацію публічної влади в Україні трактують як ознаку «європейськості» та умову наближеності до стандартів Європейського Союзу, спробуємо проаналізувати іiі вплив на ставлення громадян до Європейського Союзу.

Такі процеси, як Brexit i локдаун у зв'язку з пандемією коронавірусу (COVID-19) у 2020 році поставили єдність ЄС та подальшу інтеграцію під питання. Ці події впливають на ставлення громадян до $Є С$, відмінне в різних країнах. За даними Eurobarometer, найпозитивнішим імідж $\in C$ був у травні 2017 року в Ірландії, Люксембурзі, Болгарії та Португалії, тоді як найбільш негативним - у Греціï, Чехії, Австрії і Великій Британії [1]. Однак навіть у межах цих країн ставлення до $€ С$ не було одностайним, причому субнаціональний поділ щодо ставлення до $Є C$ не $€$ ексклюзивним для Великобританії. У своєму дослідженні М. Дабровскі визначив, наскільки поширені суттєві розбіжності у ставленні до ЄС практично в кожній країні, що є іiі членом [2]. Наприклад, існує більша прихильність до ЄС на півдні Швеції, ніж у північній іï частині, тоді як у ФРН поділ існує між Східною та Західною Німеччиною. ЄС більш популярний на півночі та півдні Італії, ніж у центрі країни. В Австрії прихильність до $Є С$ найбільша у Відні та нижній Австрії, у Греції - у Західній Македонії і Фракіiі. Чим викликані та що означають ці просторові відмінності у сприйнятті ідеалу ЄС? Проведені дослідження M. Габела та X. Палмера довели, що різниця в економічних перевагах від інтеграції є основою відмінностей ставлення до $Є С$ та ідеї євроінтеграції загалом [3]. Нещодавнє дослідження В. Айелло виявило, що «ставлення до ЄС зумовлене сприйняттям індивідами економіки у своєму регіоні та ефективністю інституцій $\in C$ у вирішенні регіональних проблем» [4, с. 673]. Отже, відмінності в реалізації регіональної влади впливають на ступінь прихильності громадян до європейського проекту.

EC заохочує держави-члени покласти більше відповідальності на місцеві органи влади через низку спрямованих на посилення 
«локалізму» заходів. У країнах з усталеними федеративними або децентралізованими системами, таких як Німеччина, вплив подібного роду дій $€ C €$ мінімальним. Навпаки, у країнах із високим рівнем централізації, таких як Польща, країни Центральної і Східної Європи, ЄС відіграє значну роль у розробленні проєктів децентралізації та передачі влади й ресурсів на субнаціональні рівні управління $[5 ; 6]$. Децентралізацію у країнах ЄC розглядають як один із позитивих наслідків європейського проєкту, проте збільшення субнаціональної автономії підживлює «локалізм», часто шкодячи європейській єдності.

Мета роботи - дослідження зв'язку між децентралізацією і прихильністю європейських громадян до європейського проекту. Під час дослідження використовувалися результати опитування Євробарометру, проведені з 1973 до 2002 року. Завданням дослідження $€$ вивчення впливу децентралізації публічної влади на ставленння людей до європейської інтеграції, що дозволить нам оцінити, чи існує потенційний компроміс між «локалізмом» та «європеїзмом».

Період, який досліджується, обмежений 1973 та 2002 роками за кількох причин. Європейський інтеграційний процес, що розпочався зі створення Європейської спільноти вугілля і сталі в 1952 році, характеризується багатьма історичними подіями: від будівництва Берлінської Стіни влітку 1961 р. та фінансових проблем в Європейському економічному співтоваристві 1965 р. до відносно сучасних викликів, пов'язаних із розширенням ЄC у 2004 та 2007 рр., економічною кризою 2008 р. та кризою біженців 2015 року. Помітно, що в кризові періоди громадяни були більш скептичними щодо оцінки переваг європейської інтеграції, а під час економічного буму - частіше підтримували європейську інтеграцію [7-9]. Отже, історичні подіi, потрясіння і виклики створили високий ступінь неоднорідності щодо сприйняття громадянами переваг європейської інтеграції та єдиного ринку ЄС. Це ставлення варіюється не тільки в різних регіонах об'єднаної Європи, але й за часом. Загалом період 1973-2002 рр. відзначається вищим ступенем однорідності, ніж період 2003-2020 рр., адже громадяни зазвичай позитивніше тоді оцінювали ЄС. До двох великих розширень $Є C$, незважаючи на певні злети й падіння, здебільшого розглядався як взірець демократії, процвітання і політичної стабільності.

Одним із показників демократії вважався саме ступінь децентралізації влади та місцевої автономії. Цей період характеризується розквітом вже децентралізованої Австрії і Західної Німеччини; Бельгія та Іспанія також зазнали глибоких перетворень у територіальній організації. Деволюція повноважень та ресурсів відбувалася в Італії, тоді як Франція і Велика Британія були більш обережні під час децентралізації. Країни Центральної i Східної Європи, такі як Польща, почали надавати більше повноважень та ресурсів регіонам.

Деякі частини Східної Європи, що приєдналися до ЄС у 2004 та 2007 роках, дуже прагнули швидко стати повністю європейськими, але між „західними” та „східними” моделями реалізації публічної влади i в наш час залишаються значні відмінності. Більше того, останні дослідження показують, що відмінності у підтримці різними державами європейської інтеграції зросли після розширення ЄС та економічної кризи. Більшість дослідників погоджуються 3 негативною роллю економічної кризи в посиленні опозиції європейській інтеграції. До того ж Д. Тошков та Е. Кортенська наголошують, що посилення імміграції підірвало громадську підтримку інтеграції в ЄС [9]. Усі ці фактори разом із локдауном 2020 року радикально змінили характер очікувань громадян від $Є С$. 
Актуальність нашого дослідження визначається так: це перша спроба оцінити вплив децентралізації у країнах ЄC 1973-2002 років на ставлення громадян до європейського проєкту. Цей підхід відрізняється від існуючих емпіричних досліджень впливу децентралізації, оскільки попередні дослідження зазвичай зосереджувалися на аналізі економічних показників. Це дослідження може пояснити суперечливі висновки макроекономічного аналізу, за яким не оцінювалася децентралізація 3 погляду на суб'єктивне ставлення громадян, і досліджує зв'язок між децентралізацією та оцінкою європейської єдності. Висновки щодо впливу децентралізації на ставлення громадян до ЄС протягом 1973-2002 рр. можуть бути використані задля вдосконалення політики децентралізації в Україні.

ЄC давно визнав роль місцевої влади та загалом підтримав децентралізацію як інструмент просування європейського ідеалу й досягнення кращих результатів економічного розвитку. Тому децентралізація часто розглядалася як ключовий фактор, який визначає просування справедливості та ефективності на місцевому, регіональному, національному та європейському рівнях. Однак ступені децентралізації у країнах та регіонах Європи донині залишаються вкрай нерівномірними. Поки деякі країни робили обмежені кроки до децентралізації, інші вже передали значні обсяги владних повноважень та ресурсів місцевому рівню, їхні регіони й міста вже користуються значним ступенем автономіі. За останні чотири десятиліття тенденція до децентралізації була поширеною в Європі, проте процес залишався нерівномірним. Наприклад, європейські країни 3 найвищим ступенем децентралізації (Австрія, Бельгія, Німеччина, Італія, Іспанія) мали або запроваджували інституційні, політичні, законодавчі та інші реформи, які зробили їхні регіони важливими самостійними субєктами у багатьох сферах державної політики. Інші європейські країни залишаються, навпаки, високо централізованими. Регіони у країнах Балтіі, Греціі, Ірландіі, Португалії мають дуже незначну автономію і $€$ не більше, ніж адміністративними одиницями.

Згідно з економічними та політологічними дослідженнями, децентралізація влади може мати як позитивний, так і негативний вплив на економічні показники країни та на добробут громадян. 3 одного боку, передача повноважень та ресурсів субнаціональним рівням управління може призвести до зростання ефективності економіки, тому що органи місцевого самоврядування більше здатні адекватно виконувати державні функції відповідно до вподобань громадян, які проживають у різних регіонах країни. Децентралізація також може мобілізувати не досить використані ресурси, створюючи конкуренцію серед субнаціональних урядів і забезпечуючи кращі результати політики [10]. Загальновизнано, що органи місцевого самоврядування мають інформаційні переваги перед центральними урядами щодо потреб місцевих жителів, на підставі чого місцеві чиновники можуть краще спроектувати та впроваджувати політику на місцевому рівні, ніж посадові особи в центральних урядах. Отже, децентралізація може наблизити уряд до людей, тим самим сприяючи більшій прозорості й підзвітності. Більша децентралізація також сприяє прозорості та висвітлює відмінності в забезпеченні суспільними благами та послугами на різних територіях, зменьшує можливості корупції. Місцеві органи влади також мають політичні стимули задля забезпечення зростання економічного розвитку й соціального задоволення громадян, щоб схилити їні голоси за свої партії на виборах.

3 іншого боку, децентралізація і регіональна автономія здатні 
підірвати можливості центральної влади держав ЄС у виконанні важливої соціальної функції - вирівнювання соціальних можливостей громадян у різних регіонах. За відсутності чіткої підзвітності місцевої влади децентралізація може сприяти захопленню локальною елітою всіх повноважень публічної влади, і, як наслідок, збільшити соціальну роздробленість та знизити добробут громадян. Окрім того, в бідних регіонах із нерозвиненою економікою децентралізація може не призвести до кращого узгодження суспільних благ та послуг з потребами населення, адже децентралізація пов'язана $з$ додатковими бюрократичними витратами, що виникають внаслідок збільшення шарів управління. Бідні країни не можуть собі дозволити додаткові витрати, пов'язані зі створенням зайвих інституцій.

Загалом не існує остаточної оцінки балансу між недоліками та перевагами децентралізаціі. Що ж визначає громадську підтримку або протидію європейській інтеграції? Чи пояснюють відмінні недоліки та переваги децентралізації у країнах-членах різницю у сприйнятті ЄC? Теорія соціально-політичного сприйняття може допомогти нам зрозуміти, як громадяни ставляться до об'єднаної Європи. Загальновідомо, що сприйняття - це складний процес, в якому беруть участь різноманітні психологічні чинники. Науковці поділили детермінанти сприйняття на дві категоріі: особистісні характеристики (композиційні ефекти), такі як стать, вік, освіта, та середовищні характеристики (контекстні ефекти), що стосуються соціально-економічного й політичного середовища, в якому живе людина [11]. У цій роботі ми розглядаємо, чи може децентралізація влади, яка, незаперечно, є впливовим чинником середовища, сформувати ставлення людей до європейської інтеграції.

Переваги європейської інтеграціï багатовимірні, однак вона також має певні недоліки як для приватних осіб, так і для фірм: це, насамперед, виклики вітчизняним виробникам i навіть національним державам із приводу втрати їхніх повноважень у багатьох сферах. Більшість цих переваг і недоліків можна виміряти об'єктивними показниками, але громадяни використовують інші суб'єктивні та багатовимірні критерії підтримки або протидії європейській інтеграції. За даними М. Гавела [12], п'ять теорій створюють теоретичну основу для пояснення відмінностей у суспільному ставленні до європейської інтеграціі: 1) теорія когнітивної мобілізації, за якою висока політична обізнаність і добре розвинені навички у політичній комунікації дозволяють ідентифікувати себе з ЄС; 2) теорія політичні цінності, відповідно до якої політичне ставлення людей визначається умовами, в яких вони формувалися; 3) теорія утилітарних оцінок інтегративної політики, де громадяни з різним рівнем прибутку стикаються 3 різними недоліками та перевагами європейської інтеграції, отже, їхня підтримка інтеграції пов'язана 3 очікуваннями потенційних переваг у сфері добробуту; 4) теорія класової причетності, за якою громадяни ставляться до інтеграції так само, як і до політичних партій; 5) теорія державної підтримки, за якої співпадає підтримка інтеграції та національного уряду. Потенційний вплив децентралізації влади на сприйняття громадянами $\in C$ переважно пов'язаний із теорією утилітарних оцінок інтегративної політики, оскільки громадяни ЄC по-різному відчувають плюси та мінуси децентралізації, отже, з цих відмінностей формується їхнє сприйняття та ставлення до європейської інтеграції. 3 одного боку, децентралізація через «локалізм» може посилити опозицію до Європи, а з іншого боку, децентралізація через «європеїзм» може посилити підтримку Європи. Децентралізація забезпечує різний ступінь соціальної допомоги й витрат 
для громадян $Є С$, що відображає відмінності в підтримці або протидії об'єднаної Європи. Передача ресурсів і повноважень на субнаціональний рівень влади впливає на підтримку особою європейської інтеграції.

Громадяни Бельгії, Франції, Німеччини, Італї, Люксембурга та Нідерландів традиційно дотримуються більш позитивного, ніж негативного ставлення до ЄС. Окрім них країнами із традиційно позитивними поглядами на ЄC були Ірландія, Португалія, Іспанія i, до спалаху кризи, - Греція. На відміну від них австрійці, датчани, фіни, шведи, британці більш скептично ставилися до інтеграції $Є$. Можна стверджувати, що громадяни країн, які триваліше є членами $\in C$, мають більш позитивне ставлення до європейської інтеграції, ніж жителі країн, які приєдналися пізніше.

Під час аналізу децентралізації на рівні країни використовуються два показники: субнаціональна частка в загальних державних витратах і субнаціональна частка в загальних доходах держави. Хоча ці показники можна вважати такими, що відображають маштаб і складність процесу децентралізації, їх критикують за неправильне визначення реального рівня фінансової автономії, яка надається субнаціональним урядам у разі недиференціації інших показників. Рівень політичної децентралізації вимірюється за допомогою індексу регіональних органів влади (відомий як $R A I$ iндекс). Індекс RAI - це сума балів двох показників: самоврядування стосовно повноважень, які здійснює регіональний уряд щодо жителів регіону, та загального врядування стосовно повноважень, які здійснюються регіональним урядом або його представниками в країні загалом. Цікаво, що більшість громадян, які проживають у країнах із високим рівнем фінансової децентралізації, вважали членство в ЄС менш цінним i, як наслідок, менш імовірно підтримують європейську інтеграцію.
Але громадяни країн $з$ високою політичною децентралізацією ставилися до ЄC нейтрально або позитивно. Більшість громадян у країнах з високим ступенем фінансової децентралізації були противниками подальшої економічної інтеграції, тоді як країни 3 високою політичною децентралізацією більше схильні підтримувати економічну інтеграцію. Для визначення впливу децентралізації на ставлення громадян до ЄC ми маємо аналізувати як композиційні, так і контекстні ефекти.

У цій роботі вперше з'ясовано зв'язок між децентралізацією влади та прихильністю європейських громадян до ЄС протягом 1973-2002 pр. Порівняльний аналіз показує вплив децентралізації на ставлення осіб до ЄC. Фінансова децентралізація оцінюється часткою загального державного доходу, витраченого субнаціональними урядами, і розглядається як чинник посилення підтримки громадянами європейської інтеграції. Якщо замість того, щоб зосередитися на доходах, ми розглянемо видатки, то фінансова децентралізація відіграла більш нейтральну роль в ідентифікації громадян із Європою. Отже, з погляду громадян, збільшення частки загального державного доходу, витраченого субнаціональними урядами, свідчить про економічні переваги європейської інтеграції, тоді як збільшення політичної децентралізації призводить до збільшення економічних витрат. Політична децентралізація, здається, підірвала прихильність європейських громадян до ЄС. Аналіз у цій роботі не позбавлений обмежень, переважно пов'язаних із обмеженим періодом. Коли стануть доступними відомості, аналіз буде розширено до періоду 2003-2020 рр. і досліджено наслідки ключових історичних подій на шляху європейської інтеграції, такі як розширення 2004 та 2007 років, що спричинили послаблення згуртованості в Європі; фінансово-економічна криза 2008 року, що посилила опозицію до 
європейської інтеграції; криза біженців 2015 року; Brexit i COVID-19. Незважаючи на обмеження цього дослідження, політики можуть використати його висновки для проєктування Європейської політики. Крім того, дослідження також $є$ актуальним у контексті євроінтеграційного курсу України. Якщо ЄС продовжує сприяти добробуту громадян і країн шляхом більшої європейської інтеграціï ("європеїзм"), одночасно сприяючи автономії місцевої влади у країнах-членах («локалізм»), то вплив децентралізації на прихильність громадян до європейського проєкту має враховуватися й українськими політиками. Результати аналізу показують, що обидві цілі («європейство» та «локалізм») реалізовувалися протягом 1973-2002 рр. Децентралізація доходів, а не політична децентралізація стимулювала підтримку $Є C$ громадянами, тому необхідно шукати оптимальну політику для досягнення обох цілей як в ЄС, так і в Україні.

У статті проаналізовано вплив децентралізації публічної влади на ставлення громадян до Европейського Союзу з метою оцінити, ии існуе потениійний компроміс між «локалізмом» та „європеїзмом”. Автором зазначено, що децентралізація традиційно розглядалася як ключовий фактор, який визначає просування справедливості та ефективності на місцевому, регіональному, національному та європейському рівнях, але ступінь деиентралізації у країнах $i$ регіонах Європи залишається нерівномірним. У результаті дослідження визначено, що відмінності в реалізації регіональної влади впливають на ступінь прихильності громадян до європейського проекту. Децентралізацію у країнах ЄС розглядають як один із сприятливих наслідків європейського проєкту, але збільшення субнаціональної автономії підживлюе «локалізм», часто на щкоду європейській єдності. Визначено, що у кризові періоди громадяни більш скептично відносяться до очінки переваг європейської інтеграціï, а під час економічного зростання - частіше підтримують європейську інтеграиію. 3 іншого боку, децентралізаиія $і$ регіональна автономія здатні підірвати можливості иентральної влади держав EC у виконанні важливої функції - вирівнювання соиіальних можливостей громадян різних регіонів. У дослідженні наголошено, що відмінності в підтримиі різними державами європейської інтеграції зросли після розширення ЄC та економічної кризи, причому більшість дослідників погоджуються з негативною роллю економічної кризи в посиленні опозиції європейській інтеграції. Потениійний вплив децентралізаціі влади на сприйняття громадянами ЕС автор пояснюе теорією утилітарних оцінок інтегративної політики, оскільки громадяни ЕС по-різному відчувають плюси й мінуси децентралізації, отже, з ичих відмінностей формується їхне сприйняття $i$ ставлення до європейської інтеграизї. Зроблено висновок про суттєві розбінності у ставленні громадян до иієї спільноти у просторі й часі в кожній країні-илені ЄC.

Ключові слова: децентралізація, публічна влада, Європейський Союз, місцева автономія.

Stohova O. The influence of decentralization of government on the attitude of citizens to the European Union

The article analyzes the impact of decentralization of public power on citizens' attitudes towards the European Union in order to assess whether there is a potential compromise between «localism» and «Europeanism». The author notes that decentralization has traditionally been seen as a key factor in promoting justice and efficiency at 
local, regional, national and European levels, but the degree of decentralization in European countries and regions remains uneven. The study found that differences in the implementation of regional government affect the degree of citizens' commitment to the European project. Decentralization in the $E U$ is seen as one of the positive consequences of the European project, but increasing subnational autonomy fuels «localism», often to the detriment of European unity. It is determined that in times of crisis, citizens are more skeptical about assessing the benefits of European integration; and during economic growth they are more likely to support European integration. On the other hand, decentralization and regional autonomy can undermine the capacity of the central government of the EU to perform an important function equalizing the social opportunities of citizens in different regions. The study notes that differences in different countries' support for European integration have increased since the $E U$ enlargement and the economic crisis, with most researchers agreeing with the negative role of the economic crisis in strengthening opposition to European integration. The author explains the potential impact of decentralization on the perception of $E U$ citizens by the theory of utilitarian assessments of integrative policy, as EU citizens experience the pros and cons of decentralization differently, and therefore, these differences shape their perception and attitude to European integration. It is concluded that there are significant differences in the attitude of citizens to the $E U$ in space and time in each member state.

Key words: decentralization, public authority, European Union, local autonomy.

\section{Література}

1. Eurobarometer. Standard Eurobarometer 87. Public Opinion in the European
Union. Key Trends. Brussels and Luxembourg: Publication Office of the European Union. 2017.

2. Dabrowski M., Dominic S., Bardia M. Towards a Regional Typology of EU Identification: Cohesify Research Paper 6. Delft: Delft University of Technology. 2017.

3. Gabel M., Harvey D. P. Understanding variations in public support for European Integration. European Journal of Political Research. 1995. No 27. P. 3-19.

4. Aiello V., Pierre M. R., Cristina B. European identity and citizens' support for the EU: Testing the utilitarian approach. Regional Science Policy and Practice. 2019. No 11. P. 673-694.

5. Brusis M. Between EU requirements, competitive politics, and national traditions: Re-creating regions in the accession countries of Central and Eastern Europe. International Journal of Policy and Administration. 2002. No 15. P. 531-559.

6. Bruszt L. Multi-level governance The Eastern versions: Emerging patterns of regional developmental governance in the new member states. Regional and Federal Studies. 2008. No 18. P. 607-627.

7. Jones E., Kelemen D., Meunier S. Failing Forward? The Euro Crisis and the Incomplete Nature of European Integration. Comparative Political Studies. 2016. No 49. P. 1010-1034.

8. Kuhn T., Florian S. When European integration becomes costly: The euro crisis and public support for European economic governance. Journal of European Public Policy. 2014. No 21. P. 624-641.

9. Toshkov D., Kortenska E. Does Immigration Undermine Public Support for Integration in the European Union? JCMS-Journal of Common Market Studies. 2015. Vol. 53. P. 910-912.

10. Rodrrguez-Pose A., Ezcurra R. Does decentralization matter for regional disparities? A cross-country analysis. Journal of Economic Geography. 2010. No 10. P. 619-644.

11. Lakey B., McCabe K.M., Fisicaro S.A., Drew J.B. Environmental and personal determinants of support perceptions: Three generalizability studies. Journal of Personality and Social Psychology. 1996. Vol. 70. P. 1270-1280.

12. Gabel M. Public support for European integration: An empirical test of five theories. Journal of Politics. 1998. No 60. P. 333-354. 